\title{
Genetic differentiation among populations of Sesleria albicans Kit. ex Schultes (Poaceae) from ecologically different habitats in central Europe
}

\author{
C Reisch ${ }^{1}$, P Poschlod ${ }^{1}$ and R Wingender ${ }^{2}$ \\ ${ }^{1}$ Lehrstuhl für Botanik, Universität Regensburg, D-93040 Regensburg, Germany; ${ }^{2}$ Institut für Landwirtschaftliche Botanik, Universität \\ Bonn, Karlrobert-Kreiten-Straße 13, D-53115 Bonn, Germany
}

\begin{abstract}
As observed for many other plant species, the populations of Sesleria albicans in Central Europe are located in habitats, which differ to a high degree from each other with regard to ecological factors such as nutrients, light and water as well as in type of land use. The species colonizes limestone cliffs, pavements, screes, grazed and mown grasslands, heaths, fens and open woodlands. In this study, we used random amplified polymorphic DNA (RAPD) analysis to investigate the genetic differentiation among 25 populations of $S$. albicans from six different types of habitat (beech forests, alpine and lowland rocky ridges, lowland screes, fens, calcareous grasslands). With RAPD analysis, 344 fragments could be amplified, of which $95.9 \%$ were polymorphic. The level of polymorphism ranged from 29.7 to $56.7 \%$
\end{abstract}

polymorphic bands per population and was correlated with population size. In an analysis of molecular variance (AMOVA), used to detect variation among individuals within populations, among populations from the same habitat and among different habitats, most of the genetic variation was found within populations $(62.06 \%)$ and among populations from the same habitat (33.36\%). In contrast, only a very low level of differentiation could be observed among different habitats $(4.58 \%)$. The results of our study give only little evidence for an ecotypic differentiation of Sesleria albicans. This differentiation is principally conceivable, but obviously not related to the investigated RAPD loci.

Heredity (2003) 91, 519-527. doi:10.1038/sj.hdy.6800350

Keywords: RAPD; fingerprint; genetic diversity; genetic differentiation; ecotype; selection

\section{Introduction}

Sesleria albicans Kit. ex Schultes (Poaceae) is an alpine, perennial grass, which is widely distributed in the Alps, but also occurs in the lower mountains of south and central Germany (Dixon, 1982). Populations of S. albicans are located in ecologically very different habitats, which means that the plant colonizes beech forests, as well as naturally and manmade open habitats such as alpine and lowland rocky ridges, lowland screes, fens or calcareous grasslands. Furthermore, the plant grows on different geological materials and under a multitude of climatic conditions. As a consequence, the habitats in which the populations of $S$. albicans are located differ to a high degree from each other with regard to ecological factors such as nutrients, light and water, just as in the type of land use by grazing or mowing (Table 1 ).

Genetic variation within and among populations is strongly affected by ecological factors (Huff et al, 1998; Kölliker et al, 1998; Hsao and Lee, 1999), and microgeographic differentiation, caused by these factors, is reported for many species (Nevo et al, 1988; Nevo and Beiles, 1989; Owuor et al, 1997; Hsao and Lee, 1999). Ecological differences among the habitats colonized by a

Correspondence: C Reisch, Lehrstuhl für Botanik, Universität Regensburg, D-93040 Regensburg, Germany

E-mail: christoph.reisch@biologie.uni-regensburg.de

Received 30 June 2002; accepted 2 May 2003 plant species can, therefore, result in the development of ecotypes (Gunter et al, 1996).

Moreover, different land-use practices are thought to make a contribution to the genetic differentiation of populations (Poschlod and Jackel, 1993; Poschlod et al, 2000). Fertilization and defoliation are generally known to cause population differentiation and different types of grassland management can result in the development of ecotypic variants (Sweeney and Danneberger, 1995; Zopfi, 1998).

$S$. albicans colonizes wet and dry, sunny and shady, manmade and natural habitats. Differences in the length and width of leaves and spikes among populations of $S$. albicans from different habitats have been observed under common garden conditions (Dixon, 1982) and the populations growing in fens are supposed to be separate varieties or ecotypes. Furthermore, a morphometric analysis (Reisch and Poschlod, 2003) indicates differentiation among populations of S. albicans. Genetic or ecotypic differentiation among the populations of $S$. albicans, which grow in different habitats and under variable ecological conditions, can therefore be supposed.

In the past decade, the detection of genetic diversity has been improved by the advent of new molecular techniques. Different methods of DNA fingerprinting have proved to be useful tools with a wide range of applications in plant population genetic studies, such as the detection of genetic variation within and among populations, the characterization of clones, the analysis 
Table 1 Habitats in which the sampled populations of S. albicans were located

\begin{tabular}{|c|c|c|c|c|}
\hline Habitats & $\begin{array}{l}\text { Temperature } \\
\text { fluctuations }\end{array}$ & $\begin{array}{l}\text { Water } \\
\text { fluctuations }\end{array}$ & $\begin{array}{l}\text { Nutrient } \\
\text { stress }\end{array}$ & $\begin{array}{l}\text { Type of } \\
\text { land use }\end{array}$ \\
\hline Lowland scree & High & High & High & None \\
\hline Alpine rocky ridge & High & High & High & None \\
\hline Lowland rocky ridge & High & High & High & None \\
\hline Calcareous grassland & Medium & Medium & Medium & Grazing \\
\hline Fen & Medium & None & Medium & Mowing \\
\hline Beech forest & Low & Low & Low & None \\
\hline
\end{tabular}

For each habitat, information about ecological conditions and land use is given.

of breeding systems and the analysis of ecographical variation (Weising et al, 1995).

Random amplified polymorphic DNA (RAPD) analysis has been successfully used to detect genetic variation of plant populations in a large number of studies (Fahima et al, 1999; Mengistu et al, 2000; Persson and Gustavsson, 2001; Arafeh et al, 2002) and to analyse genetic differentiation among populations from ecologically different habitats (Owuor et al, 1997; Huff et al, 1998; Kölliker et al, 1998; Hsao and Lee, 1999). Moreover, the analysis of molecular variance technique (AMOVA) (Excoffier et al, 1992) is a powerful tool to analyse RAPD marker variation within and among plant populations (Huff et al, 1993; Huff, 1997). In the study presented here, we therefore used RAPDs and AMOVA to find out whether there exists a genetic differentiation among populations from habitats, which differ from each other with regard to ecological conditions and land use.

\section{Materials and methods}

\section{Species description}

S. albicans Kit. ex Schultes (Poaceae) is a perennial grass with deeply rooting rhizomes which form small, persistent cushions of numerous tillers. The diploid $(2 n=28)$ and wind-pollinated plant usually flowers from March to June. The flowers are slightly proteandrous, and selfpollination, therefore, is probably of rare occurrence. On established plants, seed set occurs every year, although isolated plants sometimes yield very few seeds (Dixon, 1982). The species is a chamaephyte with vegetative survival and slow winter growth of leaves and developing inflorescences. No specialized propagules are produced for vegetative regeneration. Detached tillers, however, could provide an effective means of vegetative propagation.

S. albicans is widely distributed in the Alps, Carpathians and Pyrenees, but also occurs in Great Britain and Ireland, in the foothills of the Alps in France, Germany and Italy, and in the lower mountains of south and central Germany (Dixon, 1982). S. albicans also occurs in isolated sites in the plains of Poland, in the river valleys of northern France and Belgium, in the Sierra Nevada of Spain, in former Yugoslavia and Albania and in two localities in Iceland.

\section{Study sites}

To investigate the genetic diversity within and among populations of S. albicans from different types of habitats, 25 populations in southwest, west and central Germany

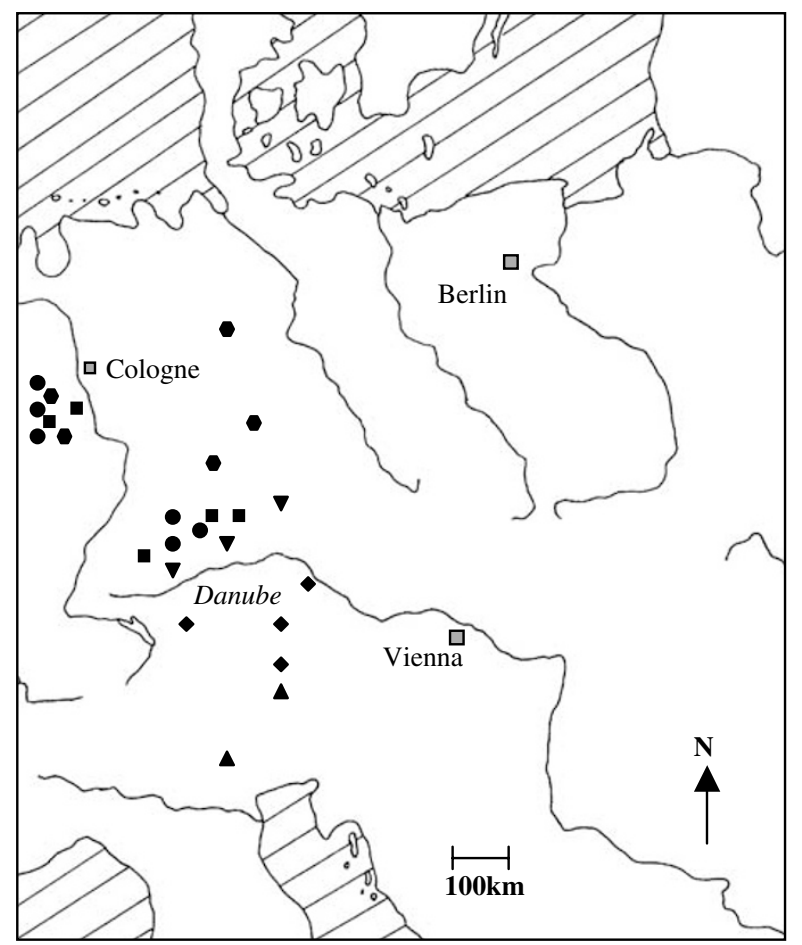

Figure 1 Geographic position of the study sites. In all, 25 populations of $S$. albicans in central Europe and the Alps were investigated. Populations grew in six different types of habitats: lowland screes (hexagons), lowland rocky ridges (inverted triangles), limestone grasslands (circles), beech forests (squares), fens (rhombuses) and alpine rocky ridges (triangles).

and in the northern and southern Alps were selected (Figure 1). Plants from six different types of habitat like lowland screes and lowland rocky ridges, calcareous grasslands, beech forests, fens and alpine rocky ridges (Table 2) were compared.

\section{Plant material and sampling conditions}

Seed material was collected in situ all across the population from at least 20 different plants, and was used to germinate plants from each population in a common garden. After germination, 10 individuals per population were planted in small pots with common garden soil and cultivated for 1 year. Since we focused on the differentiation among populations from different habitats in this study, we decided to analyse a relatively small number of plants from a large number of populations rather than a large number of plants from a small number of populations. After the first flowering of the individuals, therefore, leaves from four plants per population were sampled and stored at $-35^{\circ} \mathrm{C}$ in the laboratory.

\section{DNA isolation}

The DNA was isolated from frozen plant material of individual plants using the cetyltriammonium bromide (CTAB) method (Rogers and Bendich, 1994) adapted as follows. Approximately $40-60 \mathrm{mg}$ leaf material was ground in liquid nitrogen in a $1.5 \mathrm{ml}$ Eppendorf tube followed by addition of $700 \mu \mathrm{l}$ extraction buffer $(100 \mathrm{mM}$ Tris- $\mathrm{HCl}, \mathrm{pH}$ 9.5; $20 \mathrm{mM}$ EDTA, $\mathrm{pH} 8.0 ; 1.4 \mathrm{M} \mathrm{NaCl}$; $1 \%$ PEG; $2 \% \quad \mathrm{CTAB} ; 2.5 \mu \mathrm{l} / \mathrm{ml} \quad \beta$-mercaptoethanol). 
Table 2 Sampled populations of S. albicans with abbreviation (Abb.) description of habitat, region, geographical latitude (La.), longitude (Lo.), altitude (Alt.), number of sampled individuals (S.) and population size (P. size, in $\mathrm{m}^{2}$ covered by Sesleria)

\begin{tabular}{|c|c|c|c|c|c|c|c|c|c|}
\hline No. & Population & $A b b$. & Habitat & Region & La. (N) & Lo. (E) & Alt. & $S$. & P. size \\
\hline 1 & Mühlenbachtal & Müh & Lowland scree & CG & $51^{\circ} 27^{\prime}$ & $8^{\circ} 37^{\prime}$ & 300 & 4 & 5 \\
\hline 2 & Engelslay & Eng & Lowland scree & WG & $50^{\circ} 31^{\prime}$ & $6^{\circ} 58^{\prime}$ & 200 & 4 & 6 \\
\hline 3 & Brunkenstein & Bru & Lowland scree & WG & $49^{\circ} 49^{\prime}$ & $7^{\circ} 31^{\prime}$ & 220 & 4 & 4 \\
\hline 4 & Felsengärten & Fel & Lowland scree & SWG & $48^{\circ} 59^{\prime}$ & $9^{\circ} 12^{\prime}$ & 280 & 4 & 2000 \\
\hline 5 & Gissigheim & Gis & Lowland scree & SWG & $49^{\circ} 45^{\prime}$ & $9^{\circ} 35^{\prime}$ & 250 & 4 & 80 \\
\hline 6 & Rauher Fels & Rau & Lowland rocky ridge & SWG & $48^{\circ} 03^{\prime}$ & $8^{\circ} 59^{\prime}$ & 780 & 4 & 300 \\
\hline 7 & Spielburg & Spi & Lowland rocky ridge & SWG & $48^{\circ} 43^{\prime}$ & $9^{\circ} 45^{\prime}$ & 650 & 4 & 60 \\
\hline 8 & Indelhausen & Ind & Lowland rocky ridge & SWG & $48^{\circ} 18^{\prime}$ & $9^{\circ} 30^{\prime}$ & 600 & 4 & 100 \\
\hline 9 & Bürgle & Bür & Calcarous grassland & SWG & $48^{\circ} 17^{\prime}$ & $8^{\circ} 59^{\prime}$ & 740 & 4 & 15000 \\
\hline 10 & Zeller Horn & Zel & Calcarous grassland & SWG & $48^{\circ} 17^{\prime}$ & $9^{\circ} 00^{\prime}$ & 900 & 4 & 8000 \\
\hline 11 & Irrenberg & Irr & Calcarous grassland & SWG & $48^{\circ} 15^{\prime}$ & $8^{\circ} 56^{\prime}$ & 920 & 4 & 12000 \\
\hline 12 & Lampertstal & Lam & Calcarous grassland & WG & $50^{\circ} 22^{\prime}$ & $6^{\circ} 42^{\prime}$ & 440 & 4 & 1000 \\
\hline 13 & Steinfeld & Ste & Calcarous grassland & WG & $50^{\circ} 22^{\prime}$ & $6^{\circ} 38$ & 500 & 4 & 15000 \\
\hline 14 & Hundsrücken & Hun & Calcarous grassland & WG & $50^{\circ} 29^{\prime}$ & $6^{\circ} 34$ & 500 & 4 & 20000 \\
\hline 15 & Nähberg & Näh & Beech forest & SWG & $48^{\circ} 17^{\prime}$ & $9^{\circ} 00^{\prime}$ & 880 & 4 & 300 \\
\hline 16 & Eybachtal & Eyb & Beech forest & SWG & $48^{\circ} 40^{\prime}$ & $9^{\circ} 54^{\prime}$ & 600 & 4 & 300 \\
\hline 17 & Blindloch & Bli & Beech forest & SWG & $48^{\circ} 02^{\prime}$ & $8^{\circ} 58^{\prime}$ & 750 & 4 & 100 \\
\hline 18 & Pütz & Püt & Beech forest & WG & $50^{\circ} 32^{\prime}$ & $6^{\circ} 33^{\prime}$ & 450 & 4 & 100 \\
\hline 19 & Urfttal & Urf & Beech forest & WG & $50^{\circ} 32^{\prime}$ & $6^{\circ} 35^{\prime}$ & 450 & 4 & 1000 \\
\hline 20 & Evagarten & Eva & Fen & SWG & $47^{\circ} 52^{\prime}$ & $9^{\circ} 22^{\prime}$ & 600 & 4 & 30 \\
\hline 21 & Höll & Höl & Fen & SWG & $47^{\circ} 48^{\prime}$ & $9^{\circ} 48^{\prime}$ & 600 & 4 & 20 \\
\hline 22 & Federmähder & Fed & Fen & SWG & $48^{\circ} 28^{\prime}$ & $10^{\circ} 19^{\prime}$ & 450 & 4 & 20 \\
\hline 23 & Füssen & Füs & Fen & SWG & $47^{\circ} 36^{\prime}$ & $10^{\circ} 45^{\prime}$ & 500 & 4 & 50 \\
\hline 24 & Nebelhorn & $\mathrm{Neb}$ & Alpine rocky ridge & NA & $47^{\circ} 25^{\prime}$ & $10^{\circ} 21^{\prime}$ & 1600 & 4 & 50000 \\
\hline 25 & Eggental & Egg & Alpine rocky ridge & SA & $46^{\circ} 30^{\prime}$ & $11^{\circ} 25^{\prime}$ & 650 & 4 & 40000 \\
\hline
\end{tabular}

$\mathrm{CG}=$ Central Germany, WG = west Germany, SWG = southwest Germany, NA= northern Alps, SA = southern Alps

Incubation was at $74^{\circ} \mathrm{C}$ for 30 min shaking every 5$10 \mathrm{~min}$. Subsequently, the mixture was extracted twice with an equal volume of chloroform/isoamylalcohol (24:1), and centrifuged at $15000 \mathrm{~g}$ at $4^{\circ} \mathrm{C}$ for $10 \mathrm{~min}$. Adding an equal volume of isopropanol $\left(5^{\circ} \mathrm{C}\right)$, the DNA was precipitated and pelleted by centrifugation at $20000 \mathrm{~g}$ at $4^{\circ} \mathrm{C}$ for $15 \mathrm{~min}$. The DNA was washed with $70 \%$ cold ethanol $\left(4^{\circ} \mathrm{C}\right)$ for $5 \mathrm{~min}$ and air-dried for 15 $30 \mathrm{~min}$. The DNA was resuspended in $200 \mu \mathrm{l}$ TE buffer (10 mM Tris- $\mathrm{HCl}, \mathrm{pH}$ 8.0; 1mM EDTA, pH 8.0). The concentration was estimated spectrophotometrically (Uvikon 930, Kontron Instruments, Germany) at $260 \mathrm{~nm}$, and the purity measured by the ratio of the absorbance at 260 and $280 \mathrm{~nm}$. For, polymerase chain reaction (PCR) only template DNA was used with a purity of $1.8-2.1$ in a dilution of $15 \mathrm{ng} / \mu \mathrm{l}$.

\section{RAPD analysis}

For DNA amplification, the PCR was used with arbitrary 10-mer oligonucleotide primers (Roth, Karlsruhe, Germany) for RAPD amplification (Williams et al, 1990). All primers employed in this study were random sequence primers (Table 3 ) with $\mathrm{G}+\mathrm{C}$ contents of up to $70 \%$. A total of 75 primers were initially screened for amplification on S. albicans and 15 primers were selected, giving rise to clear reproducible and distinct banding patterns.

In a final volume of $15 \mu \mathrm{l}$, amplification mixtures contained $10 \mathrm{mM}$ Tris- $\mathrm{HCl}(\mathrm{pH} 9.5), 1.5 \mathrm{mM} \mathrm{MgCl}_{2}$, $50 \mathrm{mM} \mathrm{KCl}, 200 \mathrm{mM} \mathrm{dNTP}, 0.3 \mu \mathrm{M}$ primer, $1 \mathrm{U}$ Taq polymerase (Pharmacia, Freiburg, Germany) and $30 \mathrm{ng}$ of genomic DNA. The mixture was overlaid with two drops of mineral oil. The PCR was run in a thermal cycler (Autogene, Grant Instruments, Cambridge, UK). The thermal cycling program started with denaturation for $120 \mathrm{~s}$ at $94^{\circ} \mathrm{C}$, followed by 35 cycles of $12 \mathrm{~s}$ denaturation at $94^{\circ} \mathrm{C}, 48 \mathrm{~s}$ annealing at $36^{\circ} \mathrm{C}$ and $90 \mathrm{~s}$ extension at $72^{\circ} \mathrm{C}$. A final extension at $72^{\circ} \mathrm{C}$ for $10 \mathrm{~min}$ concluded the DNA amplification. PCR products were kept at $4{ }^{\circ} \mathrm{C}$ until they were loaded.

The amplificated products were separated on 1.5\% agarose gels in $1 \times$ TBE (Tris-borate-EDTA) buffer at $180 \mathrm{~V}$ for $1.5 \mathrm{~h}$, using a 100 base-pair ladder as a fragment size marker (Roth, Karlsruhe, Germany) and visualized by ethidium bromide staining. Each sample was repeated at least once in a separate amplification reaction.

For data scoring, the banding patterns were recorded using a trans-illuminating gel documentation system (Gel Print 2000i, BioPhotonics Corporation, Ann Arbor, USA). The image profiles and molecular weight of each band were determined by the program RFLPSCAN (Scanalytics CSPI Inc., Billerica, USA). Pictures were examined for strong, clearly defined bands which were reproducible in duplicate amplifications. Each band was scored across all individuals as either present or absent. When individuals did not give clear or not reproducible and easily scored signals, all bands of this fragment size were excluded from the analysis.

In the data matrix, the presence of a band was scored as 1 , whereas the absence of the band was coded as 0 . The basic data structure finally consisted of a binomial $(0,1)$ matrix of 100 rows, representing the investigated individuals, and 344 columns, representing the scored RAPD markers. Since RAPD markers are dominant, it was assumed that each band represented the phenotype at a single biallelic locus (Williams et al, 1990).

\section{Statistical analysis}

The binomial matrix was used to calculate the level of polymorphism (percentage of polymorphic bands) for 
Table 3 Primers employed with the number of RAPD markers obtained, their sequence, the size of the fragments, and the percentage of polymorphic markers $(\mathrm{P})$ for each primer

\begin{tabular}{|c|c|c|c|c|c|c|c|}
\hline Primer & Sequence $\left(5^{\prime} \rightarrow 3^{\prime}\right)$ & {$[C G] \%$} & $\begin{array}{l}\text { Size }(b p) \\
\text { min-max }\end{array}$ & $\begin{array}{l}\text { Polymorphic } \\
\text { bands }\end{array}$ & $\begin{array}{c}\text { Monomorphic } \\
\text { bands }\end{array}$ & Total & $P(\%)$ \\
\hline P1 & -CGG TCA CTG T- & 60 & $617-2130$ & 20 & 2 & 22 & 90.9 \\
\hline P7 & -CAG TCC GAG C- & 70 & $467-2000$ & 19 & 0 & 19 & 100 \\
\hline B01 & -GTT TCG CTC C- & 60 & $487-2596$ & 23 & 1 & 24 & 95.8 \\
\hline B07 & -GGT GAC GCA G- & 70 & $587-2312$ & 22 & 2 & 24 & 91.7 \\
\hline B11 & -GTA GAC CCG T- & 60 & $650-2483$ & 29 & 0 & 29 & 100 \\
\hline B18 & -CCA CAG CAG T- & 60 & $210-4123$ & 26 & 0 & 26 & 100 \\
\hline D11 & -AGC GCC ATT G- & 60 & $624-2572$ & 22 & 2 & 24 & 91.7 \\
\hline D12 & -CAC CGT ATC C- & 60 & $512-2500$ & 21 & 0 & 21 & 100 \\
\hline I01 & -ACC TGG ACA C- & 60 & $441-2170$ & 34 & 1 & 35 & 97.1 \\
\hline I04 & -CCG CCT AGT C- & 70 & 510-2075 & 23 & 1 & 24 & 95.8 \\
\hline I15 & -TCA TCC GAG G- & 60 & $776-2349$ & 10 & 1 & 11 & 90.1 \\
\hline I16 & -TCT CCG CCC T- & 70 & $450-2383$ & 20 & 1 & 21 & 95.2 \\
\hline $160 / 3$ & -CTA CAC AGG C- & 60 & $499-2777$ & 22 & 2 & 24 & 91.7 \\
\hline $160 / 4$ & -GTC CTT AGC G- & 60 & $330-2262$ & 22 & 1 & 23 & 95.7 \\
\hline $170 / 1$ & -CAT CCC GAA C- & 60 & $644-2141$ & 17 & 0 & 17 & 100 \\
\hline Total & & & $210-4123$ & 330 & 14 & 344 & 95.9 \\
\hline
\end{tabular}

each population and to compute similarities between individuals of $S$. albicans using the Jaccard's similarity coefficient, calculated as $J=a /(n-d)$, where $a$ is the number of positive matches (ie the presence of a band in both samples), $d$ is the number of negative matches (ie the absence of a band in both samples) and $n$ is the total sample size including both the numbers of matches and 'unmatches'. The genetic distances were calculated as $\mathrm{GD}=1-J$, using the data from the Jaccard's similarity coefficient matrix.

The genetic relatedness among individuals was obtained by clustering. Dendrograms were generated from the similarity coefficient matrix using the UPGMA method (Sneath and Sokal, 1973). The calculation of the Jaccard's similarity coefficient matrix and the generation of the bootstrapped dendrograms was done with the program TREECON 1.3b (van de Peer and de Wachter, 1994).

The binomial matrix was also applied to an AMOVA in RAPD patterns by the program WINAMOVA 1.55 (Excoffier et al, 1992; Stewart and Excoffier, 1996). AMOVA was originally developed for RFLP haplotypes, but it is also appropriate for RAPD phenotypes (Huff et al, 1993). AMOVA analyses were based on the pairwise squared Euclidian distances among molecular phenotypes, which are equal to the number of different band states, because band states can only take the values 0 or 1 . Since a sum of squares in a conventional analysis of variance (ANOVA) can be written as a sum of all squared pairwise differences, AMOVA is closely related to ANOVA. It allowed the calculation of variance components and their significance levels for variation among groups of populations, among populations within groups and within populations. The program extracts analogies of F-statistics (so-called $\Phi$-statistics). The homogeneity of molecular variance in pairs of populations was tested using Bartlett tests (Bartlett, 1937), which are also implemented in the WINAMOVA 1.55 program. Pairwise genetic distances $\left(\Phi_{\mathrm{ST}}\right)$ among the 25 populations and their levels of significance were also obtained from the AMOVA. For each analysis, 1000 permutations were performed to obtain significance levels. As significance tests in AMOVA are based on permutation procedures, they are essentially assumption free (Excoffier et al, 1992). Additionally, the AMOVA sums of squares divided by $n-1$ were calculated for each population to describe the molecular variance within the populations.

\section{Results}

\section{RAPD banding and levels of polymorphism}

In the RAPD analysis of 100 individuals from 25 populations of $S$. albicans with 15 decamer random primers, 344 reproducible fragments were amplified with a varying number per primer. For example, primer I01 produced 35 scorable bands, while primer I15 only amplified 11 fragments (Table 3). The size of the amplified fragments ranged from 210 to $4123 \mathrm{bp}$. The 15 primers produced between 90.1 and $100 \%$ polymorphic bands. In total, $95.9 \%$ of the bands were polymorphic, and only $4.1 \%$ were scored in all individuals from all populations. Reflecting this high level of polymorphism, all investigated individuals showed their own RAPD phenotypes.

The percentage of polymorphic bands per population ranged from $29.7 \%$ in the Federmähder population to $56.7 \%$ in the Eggental population (Table 4) and correlated highly significantly with population size (Spearman's rank-correlation coefficient $r_{\mathrm{s}}=0.7, P<0.001$ ).

\section{Genetic distances $\left(\Phi_{\mathrm{ST}}\right)$ among populations}

In all, 273 of the 300 pairwise genetic distances $\left(\Phi_{\mathrm{ST}}\right)$ between populations were highly significant. Only two had levels of marginal significance $(P<0.05)$. Maximum $\Phi_{\mathrm{ST}}$ (varying from 0 to 1 ) was 0.63 , found between the southwest German population Federmähder and the west German population Engelslay. Minimum $\Phi_{\mathrm{ST}}$ was only 0.13 , which was observed between populations Lampertstal and Urfttal, both in west Germany. The matrix of 300 pairwise genetic distances $\left(\Phi_{\mathrm{ST}}\right)$ among the 
Table 4 Genetic diversity within populations of $S$. albicans measured as percentage of polymorphic bands per population

\begin{tabular}{rlc}
\hline No. & Population & Polymorphic bands (\%) \\
\hline 1 & Mühlenbachtal & 42.3 \\
2 & Engelslay & 39.0 \\
3 & Brunkenstein & 43.6 \\
4 & Felsengärten & 49.2 \\
5 & Gissigheim & 44.0 \\
6 & Rauher Fels & 52.8 \\
7 & Spielburg & 41.7 \\
8 & Indelhausen & 50.0 \\
9 & Bürgle & 55.6 \\
10 & Zeller Horn & 51.9 \\
11 & Irrenberg & 51.1 \\
12 & Lampertstal & 53.7 \\
13 & Steinfeld & 53.4 \\
14 & Hundsrücken & 48.5 \\
15 & Nähberg & 54.2 \\
16 & Eybachtal & 47.0 \\
17 & Blindloch & 44.0 \\
18 & Pütz & 40.4 \\
19 & Urfttal & 55.7 \\
20 & Evagarten & 48.7 \\
21 & Höll & 40.1 \\
22 & Federmähder & 29.7 \\
23 & Füssen & 50.8 \\
24 & Nebelhorn & 55.0 \\
25 & Eggental & 56.7 \\
\hline
\end{tabular}

25 populations of S. albicans was, however, not correlated significantly with the corresponding matrix of geographic distances, since the calculated Mantel test showed a correlation coefficient of $r=0.17$ and a significance of $P=0.06$.

\section{Population clustering}

In an unrooted and bootstrapped UPGMA dendrogram, based on 344 RAPD markers without any exception, all populations of $S$. albicans could be discriminated from each other (Figure 2). Except for the southwest German lowland rocky ridge populations, most investigated populations were mixed thoroughly, irrespective of their origin from different habitats. However, the south alpine population Eggental was separated from all other populations with a very high bootstrap value of $100 \%$.

\section{AMOVA analysis and variance partitioning}

Arranging the 25 populations of S. albicans in six groups according to their origin from different types of habitat, a significant level of molecular differentiation among populations from different habitats was observed. A variance of $4.58 \%$ was found among different habitats, $33.36 \%$ among populations within habitats and $62.06 \%$ within populations (Table 5).

The partitioning of molecular variance was corroborated by separate three-level AMOVAs, which were conducted for the populations from southwest and west Germany only. In both cases, 61.26 and $68.23 \%$ molecular variance, respectively, were observed within the populations. Molecular variations of 2.69 and 3.38\%, respectively, were found among the different habitats. This partitioning of molecular variance was also observed, when analysing populations from different habitats, which were located close to each other in the same mountain region. Comparing only populations from the
Swabian Alb, 2.33\% variation was found among populations from different habitats. In an AMOVA conducted for the populations from the Eifel, $0.90 \%$ variation was observed among populations from beech forests and calcareous grasslands (Table 5).

The AMOVA calculation of molecular variance (Bartlett test) was carried out for all investigated populations. Molecular variance was significantly different among the 25 populations $(P<0.001)$. Of the 300 pairwise Bartlett tests of homogeneity of population variation, all tests showed highly significant differences between the populations. The variation in RAPD banding patterns among populations, among populations within habitats and within populations was also highly significant (AMOVA, $P<0.001$ ). The correlation of RAPD phenotypes within habitats relative to the correlation of random pairs drawn from the whole sample $\left(\Phi_{\mathrm{ST}}\right)$ was 0.38 . The correlation among random phenotypes within populations relative to the correlation of random pairs drawn from the whole sample $\left(\Phi_{\mathrm{CT}}\right)$ was 0.35 , and the correlation of random phenotypes within habitats, relative to that of random pairs drawn from the population $\left(\Phi_{\mathrm{SC}}\right)$ was 0.045 .

\section{Discussion}

In the investigation presented here, $95.9 \%$ of the RAPD fragments were polymorphic. Compared to other plant species, S. albicans, therefore, showed a high level of genetic variability. In a study of the widespread Tanacetum vulgare, $85 \%$ polymorphic bands were observed (Keskitalo et al, 1998), in the rare Vicia pisiformis 7.2\% (Black-Samuelsson et al, 1997) and in apomictic species of Rosa section Caninae only 3\% (Werlemark and Nybom, 2001). These differences are not astonishing, since the level of genetic variability strongly depends on the plant's life history traits (Hamrick and Godt, 1990; Nybom and Bartish, 2000). S. albicans is a perennial, allogamous plant species with a very broad ecological amplitude and these biological characteristics all contribute to create and maintain the observed high level of genetic variability (Babbel and Selander, 1974; Hamrick and Godt, 1990; Ge et al, 1999; Nybom and Bartish, 2000). Considering the intrapopulational genetic diversity of $S$. albicans, our study revealed a strong correlation of genetic variability and population size, as demonstrated for many other species (Frankham, 1996; Godt et al, 1996; Fischer and Matthies, 1998; Menges and Dolan, 1998). We observed low levels of variation in populations from fens and lowland screes, which were the smallest, and high levels of variation in populations from calcareous grasslands, which were the largest populations (Table 2). Since possible ecotypic differentiations are often superimposed by population genetic processes such as founder effects or genetic drift (Nevo et al, 1988), it is more likely that the different levels of intrapopulational diversity are due to the effects of population size rather than the influence of ecological conditions.

The habitats colonized by S. albicans differ to a high degree from each other with regard to the availability of nutrients, light and water as well as the type of land use (Table 1). As known from former investigations, genetic variation within and among populations is strongly affected by ecological factors (Nevo et al, 1988; Nevo and Beiles, 1989; Kölliker et al, 1998). The ecotypic 
Genetic distance (Jaccard)

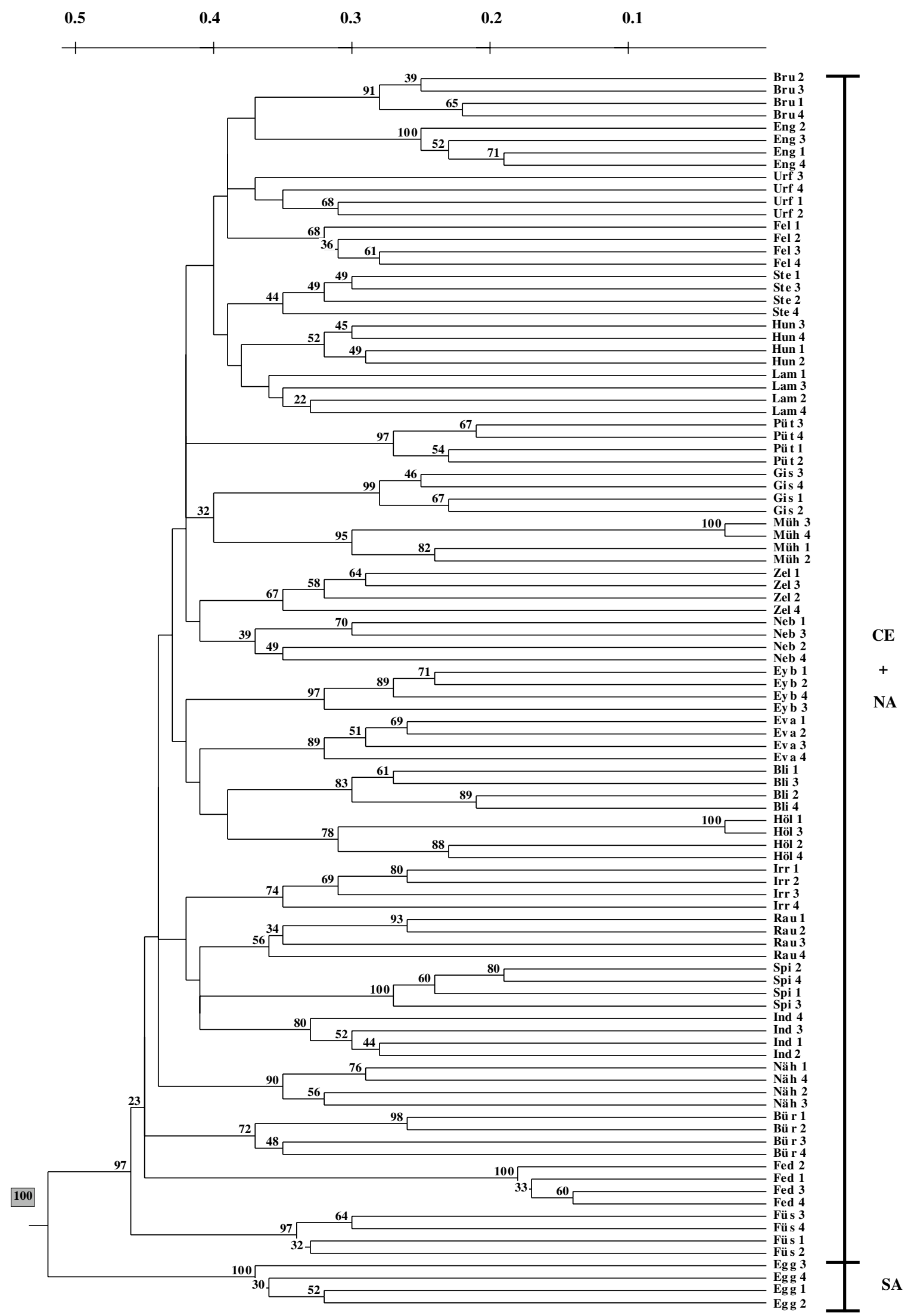

Figure 2 Bootstrapped cluster analysis (UPGMA) of 25 populations of S. albicans $(\mathrm{CE}=$ central Europe, NA=northern Alps, $\mathrm{SA}=$ southern Alps). Population abbreviations follow Table 2. 
Table 5 Summary of analysis of molecular variance (three-level AMOVA)

\begin{tabular}{|c|c|c|c|c|}
\hline Level of variation & $S S$ & $M S$ & $\%$ & $P$ \\
\hline \multicolumn{5}{|c|}{25 populations grouped together in six types of habitat } \\
\hline Among habitats & 552.488 & 110.498 & 4.58 & $<0.001$ \\
\hline Among populations within habitats & 1518.391 & 79.915 & 33.36 & $<0.001$ \\
\hline Within populations & 1902.500 & 25.367 & 62.06 & $<0.001$ \\
\hline \multicolumn{5}{|c|}{ Populations from southwest Germany grouped together in five types of habitats } \\
\hline Among habitats & 387.675 & 96.919 & 2.69 & $<0.001$ \\
\hline Among populations within habitats & 838.953 & 83.896 & 36.06 & $<0.001$ \\
\hline Within populations & 1125.500 & 25.011 & 61.26 & $<0.001$ \\
\hline \multicolumn{5}{|c|}{ Populations from west and central Germany grouped together in five types of habitats } \\
\hline Among habitats & 159.875 & 79.937 & 3.38 & 0.075 \\
\hline Among populations within habitats & 334.375 & 66.875 & 28.38 & $<0.001$ \\
\hline Within populations & 602.500 & 25.104 & 68.23 & $<0.001$ \\
\hline \multicolumn{5}{|c|}{ Populations from the Swabian Alb grouped together in three types of habitats } \\
\hline Among habitats & 172.944 & 86.472 & 2.33 & $<0.001$ \\
\hline Among populations within habitats & 452.333 & 75.389 & 30.82 & $<0.001$ \\
\hline Within populations & 715.750 & 26.509 & 66.85 & $<0.001$ \\
\hline \multicolumn{5}{|c|}{ Populations from the Eifel grouped together in two types of habitats } \\
\hline Among habitats & 63.191 & 63.192 & 0.90 & $<0.001$ \\
\hline Among populations within habitats & 180.208 & 60.069 & 22.52 & $<0.001$ \\
\hline Within populations & 414.000 & 27.600 & 76.58 & $<0.001$ \\
\hline
\end{tabular}

In all, 25 populations of S. albicans were investigated from six different types of habitat (Table 1). The analysis was based on RAPD phenotypes consisting of 344 band states. Levels of significance were based on 1000 iteration steps (SS: sums of squares, MS: mean squares, \%: proportion of genetic variability, $P$ : level of significance).

development of populations depends on climatic and edaphic conditions (Nevo et al, 1988) and differences among populations referring to these factors can cause microgeographic differentiation, as reported for many grass species (Hamrick and Allard, 1972; Hsao and Rieseberg, 1994; Nevo et al, 1994; Owuor et al, 1997). Furthermore, different types of land use are thought to make a contribution to the differentiation among and within populations (Poschlod and Jackel, 1993; Poschlod et al, 2000). Ecological differences among meadows and pastures in fertilization and defoliation can cause microenvironmental adaptations of plant populations (van Tienderen and van der Toorn, 1991; Sweeney and Danneberger, 1995) and development of ecotypic variants (Zopfi, 1993, 1998).

Considering these facts, an ecotypic differentiation among the populations of S. albicans, which grew in different habitats under various ecological conditions, could have been assumed. However, except for the southwest German lowland rocky ridge populations in an UPGMA cluster analysis, the populations were not grouped according to their origin from the same habitat. On a very large scale, the dendrogram showed a geographical pattern, since the south alpine population was separated from all other populations north of the Alps. On a smaller scale, populations were, however, not grouped geographically. This finding was corroborated by a Mantel test, which also showed no significant correlation between geographic and genetic distances. Despite colonizing ecologically differing habitats, a specific differentiation of S. albicans could not be resolved by cluster analysis based on RAPD data.

The results of the AMOVA also give only weak evidence for the ecotypic differentiation among popula- tions from different habitats. In the AMOVA, $4.58 \%$ variation was observed among the habitats, which is comparable to investigations of further grass species colonizing ecologically different habitats. In an analysis of Yushania niitakayamensis from grassland and forest undergrowth, 2.91-7.99\% variation among populations from different habitats was found (Hsao and Lee, 1999), and for Schizachyrium scoparium $3.18 \%$ variation among populations from different soil fertility levels was observed (Huff et al, 1998). Considering the genetic variation among populations from different habitats, however, the natural distribution of S. albicans in central Europe must be taken into account. Since not all types of habitat could be found in all geographic regions of central Europe, it is likely that habitat-specific and geographic effects both contribute to the observed variation among populations from different habitats in central Europe.

Considering the results of our investigation, there is only little evidence for a genetic or even ecotypic differentiation. It could, however, be possible that there is a differentiation, which is not related to the investigated RAPD loci. Such an ecotypic differentiation could possibly be detected in further investigations using different molecular methods.

\section{Acknowledgements}

We thank Wolfgang Schumacher (Bonn) for his help with the selection of the species, Jörg Wunder (Köln) for methodological discussions and Christian Willerding (Regensburg) for his help with the analysis of molecular variance. 


\section{References}

Arafeh RMH, Sapir Y, Shmida A, Iraki N, Fragman O, Comes HP (2002). Patterns of genetic and phenotypic variation in Iris haynei and I. atrofusca (Iris sect. Oncocyclus = the royal irises) along an ecogeographical gradient in Israel and the West Bank. Mol Ecol 11: 39-54.

Babbel GR, Selander RK (1974). Genetic variability in edaphically restricted and widespread plant species. Evolution 28: 619-630.

Bartlett MS (1937). Some examples of statistical methods of research on agriculture and applied biology. J $R$ Stat Soc 4: 137-170.

Black-Samuelsson S, Eriksson G, Gustafsson L, Gustafsson P (1997). RAPD and morphological analysis of the rare plant species Vicia pisiformis (Fabaceae). Biol J Linn Soc 61: 325-343.

Dixon JM (1982). Biological flora of the British Isles 151: Sesleria albicans Kit ex Schultes. J Ecol 70: 667-684.

Excoffier L, Smouse PE, Quattro JM (1992). Analysis of molecular variance inferred from metric distances among DNA haplotypes: application to human mitochondrial DNA restriction data. Genetics 131: 479-491.

Fahima T, Sun GL, Beharav A, Krugman T, Beiles A, Nevo E (1999). RAPD polymorphism of wild emmer wheat populations, Triticum dicoccoides, in Israel. Theor Appl Genet 98: 434-447.

Fischer M, Matthies D (1998). RAPD variation in relation to population size and plant fitness in the rare Gentianella germanica (Gentianaceae). Am J Bot 85: 811-819.

Frankham R (1996). Relationship of genetic variation to population size in wildlife. Conserv Biol 10: 1500-1508.

Ge S, Wang KQ, Hong DY, Zhang WH, Zu YG (1999). Comparison of genetic diversity in the endangered Adenophora lobophylla and its widespread congener, A. potaninii. Conserv Biol 13: 509-513.

Godt MJW, Johnson BR, Hamrick JL (1996). Genetic diversity and population size in four rare southern Appalachian plant species. Conserv Biol 10: 796-805.

Gunter LE, Tuskan GA, Wullschleger SD (1996). Diversity of populations of switchgrass based on RAPD markers. Crop Sci 36: 1017-1022.

Hamrick JL, Allard RW (1972). Microgeographical variation in allozyme frequencies in Avena barbata. Proc Natl Acad Sci USA 69: 2100-2104.

Hamrick JL, Godt MJW (1990). Allozyme diversity in plant species. In: Brown AHD, Clegg MT, Kahler AL, Weir BS (eds) Plant Population Genetics, Breeding, and Genetic Resources. Sinauer: Sunderland, MA. pp 43-63.

Hsao JY, Lee M (1999). Genetic diversity and microgeographic differentiation of yushan cane (Yushania niitakayamensis; Poaceae) in Taiwan. Mol Ecol 8: 263-270.

Hsao JY, Rieseberg LH (1994). Population genetic structure of Yushania niitakayamensis (Bambusoideae, Poaceae) in Taiwan. Mol Ecol 3: 201-208.

Huff DR (1997). RAPD characterization of heterogeneous perennial ryegrass cultivars. Crop Sci 37: 557-564.

Huff DR, Peakall R, Smouse PE (1993). RAPD variation within and among natural populations of outcrossing buffalograss [Buchloe dactyloides (Nutt.) Engelm]. Theor Appl Genet 86: 927-934.

Huff DR, Quinn JA, Higgins B, Palazzo AJ (1998). Random amplified polymorphic DNA (RAPD) variation among native little bluestem [Schizachyrium scoparium (Michx.) Nash] populations from sites of high and low fertility in forest and grassland biomes. Mol Ecol 7: 1591-1597.

Keskitalo M, Lindén A, Valkonen JPT (1998). Genetic and morphological diversity of Finnish tansy (Tanacetum vulgare L., Asteraceae). Theor Appl Genet 96: 1141-1150.

Kölliker R, Stadelmann FJ, Reidy B, Nösberger J (1998). Fertilization and defoliation frequency affect genetic diver- sity of Festuca pratensis Huds. in permanent grasslands. Mol Ecol 7: 1557-1567.

Menges ES, Dolan RW (1998). Demographic variability of populations of Silene regia in midwestern prairies: relationships with fire management, genetic variation, geographic location, population size and isolation. J Ecol 86: 63-78.

Mengistu LW, Mueller-Warrant GW, Barker RE (2000). Genetic diversity of Poa annua in western Oregon grass seed crops. Theor Appl Genet 101: 70-79.

Nevo E, Beiles A (1989). Genetic diversity of wild emmer wheat in Israel and Turkey. Structure, evolution and application in breeding. Theor Appl Genet 77: 421-455.

Nevo E, Beiles A, Krugman T (1988). Natural selection of allozyme polymorphisms: a microgeographic differentiation in wild emmer wheat (Triticum dicoccoides). Theor Appl Genet 75: 529-538.

Nevo E, Krugman T, Beiles A (1994). Edaphic natural selection of allozyme polymorphisms in Aegilops peregrina at a Galilee microsite in Israel. Heredity 72: 109-112.

Nybom H, Bartish IV (2000). Effects of life history traits and sampling strategies on genetic diversity estimates obtained with RAPD markers in plants. Perspect Plant Ecol Evol Syst 3: 93-114.

Owuor ED, Fahima T, Beiles A, Korol A, Nevo E (1997). Population genetic response to microsite ecological stress in wild barley, Hordeum spontaneum. Mol Ecol 6: 1177-1187.

Persson HA, Gustavsson BA (2001). The extent of clonality and genetic diversity in ligonberry (Vaccinium vitis-idea L.) revealed by RAPDs and leaf-shape analysis. Mol Ecol 10: 1385-1397.

Poschlod P, Dannemann A, Kahmen S, Melzheimer V, Biedermann H, Mengel C et al (2000). Genes in the landscape. Changes in central European land use and its impact on genetic diversity of plants. S.Vegetationskunde 32: 111-127.

Poschlod P, Jackel AK (1993). Untersuchungen des Diasporenregens und der Diasporenbank auf zwei Kalkmagerrasenstandorten der Schwäbischen Alb. Flora 188: 49-71.

Reisch C, Poschlod P (2003). Intraspecific variation, land use and habitat quality - a phenologic and morphometric analysis of Sesleria albicans (Poaceae). Flora 198: 1-8.

Rogers SO, Bendich AJ (1994). Extraction of total cellular DNA from plants, algae and fungi. In: Gelvin SB, Schilperoort RA (eds) Plant Molecular Biology Manual. Kluwer Academic Press: Dordrecht. pp 1-8.

Sneath PHA, Sokal RR (1973). Numerical Taxonomy. The Principles and Practice of Numerical Classification. WH Freeman: San Francisco.

Stewart CN, Excoffier L (1996). Assessing population genetic structure and variability with RAPD data: application to Vaccinium macrocarpum (American Cranberry). J Evol Biol 153-171.

Sweeney PM, Danneberger TK (1995). RAPD characterization of Pоа аппиа L. populations in golf course greens and fairways. Crop Sci 35: 1676-1680.

van de Peer Y, de Wachter R (1994). TREECON for Windows: a software package for the construction and drawing of evolutionary trees for the Microsoft Windows environment. Comput Appl Biosci 10: 569-570.

van Tienderen PH, van der Toorn J (1991). Genetic differentiation between populations of Plantago lanceolata. I. Local adaption in three contrasting habitats. J Ecol 79: 27-42.

Weising K, Nybom H, Wolff K, Meyer W (1995). DNA Fingerprinting in Plants and Fungi. CRC Press: Boca Raton.

Werlemark G, Nybom H (2001). Skewed distribution of morphological character scores and molecular markers in three interspecific crosses in Rosa section Caninae. Hereditas 134: 1-13. 
Williams JGK, Kubelik AR, Livak KJ, Rafalski JA, Tingey SV (1990). DNA polymorphism amplified by arbitrary primers are useful as genetic markers. Nucleic Acids Res 18: 6531-6535. Zopfi HJ (1993). Ecotypic variation in Rhinanthus alectorolophus (Scopoli) Pollich (Scrophulariaceae) in relation to grassland management. II. The genotypic basis of seasonal ecotypes. Flora 188: 153-173.

Zopfi HJ (1998). The genetic basis of ecotypic variants of Euphrasia rostkoviana Hayne (Scrophulariaceae) in relation to grassland management. Flora 193: 41-58. 